\section{Vision of industrial and rural harmony comes closer to reality}

\section{Tokyo}

WHAT is a technopolis? When Japan's Ministry of International Trade and Industry (MITI) dreamed up the concept several years ago to revitalize the nation's remoter regions and provide new drives for industry, local governments swamped the ministry with applications for technopolis status. No technopolis is yet complete, but one in the southern island of Kyushu, which got off to a head start, indicates what the future holds.

The MITI plan, which became law in 1983, envisages non-polluting high-technology industries set in green fields in coexistence with farming and fishing communities, a 'mother city' blessed with universities and research institutes that would feed industry with new ideas through an information network, while high-value-added goods are shipped out through a nearby airport.

Twenty-two local authorities have won technopolis status, which allows them to offer tax incentives and low-interest loans to attract new industry. The target date for completion of infrastructure is 1990.

The technopolis under development in Oita Prefecture on the north-east coast of Kyushu got under way ahead of its rivals. The mountainous and forested prefecture is a major tangerine-production area and is also a mecca of hot-spring resorts, but until the 1970 s it was suffering from a steady decline in population.

In 1979, the prefecture's newly elected governor, Morihiko Hiramatsu, a former MITI official, launched the airport-based industrial project. Oita's offshore airport was extended to accommodate cargo jets from Tokyo and Osaka, and high-tech industries began flocking to the area.

Now the peninsula boasts more than 30 high-tech companies within $50 \mathrm{~km}$ of the airport. Many of them are producers of integrated circuits, such as Toshiba, Matsushita Electric and Texas Instruments. Kyushu produces 40 per cent of Japan's integrated circuits, or 10 per cent of world production, and a large proportion comes from this region, nicknamed 'silicon peninsula'

Parallel with the airport project, Hiramatsu launched a 'one-village oneproduct' campaign which has helped revitalize the prefecture's farming and fishing communities. No prefectural funds were provided, only "moral and technical support". Each village was encouraged to produce its own characteristic product, such as shitake mushrooms, prawns and wine made from kiwi fruit. Although kiwi wine has yet to catch on, much of the prefecture's produce is shipped out along with the integrated circuits in cargo planes destined for Tokyo.

A stone's throw from the airport, Canon's plant, which manufactures "autoboy" cameras, provides a glimpse of technopolitan life on the factory floor. The plant is 50 per cent automated. Nine unmanned vehicles trundle around delivering parts to assembly robots and picking up finished goods. The vehicles have flashing lights, bumpers and play Scottish and Irish tunes to avoid knocking over unsuspecting technopolitans.

Most of these ideas come from the workers themselves - they are asked to submit two suggestions for improvements every day. Those who hit on a bright idea can win up to $¥ 50,000$ (more than $\$ 300$ ). Since the factory opened in 1982 , output has increased sixfold.

But an essential element in MITI's vision of a technopolis is lacking. Nearly all the high-tech industries are production facilities; the research and development units remain rooted in the Tokyo area. Hiramatsu admits that progress on this front has been slower. But he says that

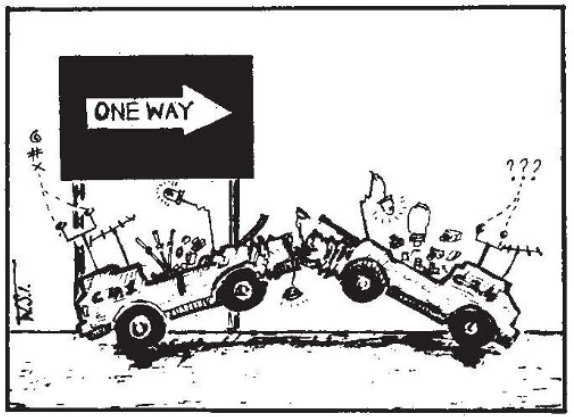

some joint projects, for example, to design new integrated circuits, have been set up between Oita University and industry.

In 1985, the technopolis's 'mother cities' of Oita and Beppu won designation from the Ministry of Post and Telecommunications as 'teletopias', which thereby entitles them to priority treatment in the establishment of a regional information network system (see Nature 305, 36; 1983). And an optical fibre cable is being laid between the two cities. By fiscal 1988, under MITI's 'new media community project' the information network will be extended to all parts of the technopolis via, for example, community antenna television. But it is yet to be seen what type of information will flow in the network.

So what is the secret of Hiramatsu's success in attracting new industries and government projects to his prefecture? The governor says that the contacts he established in his former post as director of the electronics policy division of MITI have been "very important". Furthermore, the presidents of the companies "appreciated his hospitality". David Swinbanks

\section{French pirates challenge law}

Paris

THE prosecution of a lecturer in computer science at the Paul Sabatier University of Technology, Toulouse, for illegal copying of computer programs, may lead to a change in the copyright laws. The accused, Claude Chrisment, says that the programs were copied for teaching purposes only and that the high price of commercial software, compared with relatively modest teaching budgets, makes such piracy not only necessary, but commonplace. The case has now taken on a national dimension, with hundreds of fellow computer-science lecturers publicly admitting similar offences.

Chrisment was charged following the prosecution of two of his students, in April this year, for selling copies of FF7,000 $(\$ 1,150)$ software for FF700. The students said it was Chrisment who had provided them with the original copies, as part of their course material.

In a statement published in the French newspaper La Dépêche, Chrisment's colleagues, and other senior academics from institutes in Toulouse, admitted breaking the same 1985 copyright law, which permits the purchaser of software to make one back-up copy only. The signatories have not only challenged the authorities to take action against them too, but have also written to computer-science departments throughout France, calling for support. Within two days, more than 300 "confessions' and requests for prosecution had been received.

The affair has now reached the Minister for research and higher education, Jacques Valade, who was visiting Toulouse last week, but it will not be easy to amend the copyright act. The Agence pour la Protection des Programmes (APP), who brought the initial case against the two students in April, is adamant that no change in the law is necessary. The president of APP said that "piracy is costing the software industry FF1,200 million ( $\$ 197$ million) a year, on a turnover of FF10,200 million. The contribution of copying for teaching purposes is difficult to gauge, but in any case is unjustified".

The APP has suggested lecturers use special versions of software which have been 'spiked' against commercial applications - such as accounts packages handling only 20 transactions. University lecturers, however, argue that they have a responsibility to provide students with realistic experience of widely used commercial software. They say that it would be "unprofessional" to release students onto the market without first-hand experience of major software. Peter Coles 